\title{
Stress Management Strategies: An Approach for Productive Employee Performance in the Nigerian Banking Organizations a Survey of Commercial Banking Firms in Nigeriaa
}

\author{
Joseph Teryima Sev \\ Department Of Business Management \\ Faculty of Management Sciences, Benue State University \\ Makurdi, P.M.B. 102119, Makurdi, Nigeria, West Africa.
}

\begin{abstract}
The objective of the study is to determine the impact of stress management strategies on the performance output in the commercial banking organization in Nigeria. The population of the study comprises of all the operational twenty one (21) commercial banking firms in Nigeria as at December, 2016, totaled at 64,846 employees. The sample size for the study is 398 and is determined using Taro Yamane's formula. Bowley's allocation formula is used in determining respective commercial banks sample size. Both primary and secondary sources of data collection are employed in this research, confirmatory factor analysis with Varimax rotation has been performed to examine whether the classification of the variable into the specific factors is valid or not. In this case individual approaches, organizational approaches for managing stress and consequence of stress on performance output. Kaiser-Meyer-Oikin (KMO) test is used to measure sampling adequacy accepting a weak threshold of 0.5 and Bartlett's test of Sphericity is also adopted and Total Variance Explained (TVE) score is used to measure how data is distributed within a range and also how much response differs (accepted threshold is 0.6). Cronbach Alpha $(\alpha)$ reliability test is performed to assess internal consistency of measurement adopting a weak threshold of 0.6. Multiple regression test is used in the test of two (2) formulated hypotheses. The findings of the study revealed that strategies/approaches adopted for the management of stress in the banking organizations such as realistic goal setting, placement of employees in appropriate jobs, time management, prioritizing activities and schedules amongst others will have a positive impact on performance of employee in banking organizations. Another finding reveals that consequences of stress symptoms have a significant effect on performance output of employees in the commercial banking firms in Nigeria (i.e, increase height blood pressure, anxiety, irritability, job turnover, sleep disorder, insomnia, and heart attacks amongst others). The study recommendation are that employee that are assigned responsibilities and task for performance be experienced and skillful enough to live up to expected standards of job performance so that stress will not catch up with them. Again, proper delegation of authority and responsibilities, proper job descriptions, determination of objectives of the organization, proper job designs to suit the skills and needs of the employee, establishment of employee wellness programs, proper communications amongst others, are good strategies to adopt in managing stress in banking organizations for optimal growth and performance.
\end{abstract}

Keywords: Stress, Stress Management, Strategies, Employee Performance, Stressors, Stress Consequences. 


\section{INTRODUCTION}

There appears little doubt that one of the major adverse influences of job satisfaction, work performance and productivity, and absenteeism and turnover is the incidence of stress at work. Stress is a complex and dynamic concept. It is a source of tension and frustration, and can arise through a number of interrelated influences on behaviours, including the individual, group, organizational and environmental factors [21]

According to [19] for example; in human terms any situation that is seen as burdensome, threatening, ambiguous or boring is likely to induce stress. This is the type of situation that would normally strike the individual as deserving immediate attentive or concern and is viewed unfortunate or annoying. There tends to be the feeling that the situation should not exist, but because of it, the person feels disappointed or annoyed and eventually is prone to anxiety, depression, anger, hostility, inadequacy and low frustration tolerance.

One potential major source of work stress arises from role incongruence and role conflict. Empirical surveys suggested that although a certain amount of stress may arguably be seen as a good thing and helps to promote a high level of performance, it is also potentially very harmful. Role stress can lead to difficulties in communication and interpersonal relationships and can have an adverse effect on morale, performance and effectiveness at work, and health.

Demands for improved business competitiveness and lower operating costs have frequently led to restructuring of banking, manufacturing, organization and reduction of staffing levels. This has placed greater pressures or remaining staff and resulted in a growing number of work-related health problems, work stress and a less efficient work force.

Suggests five organizational situation that are likely to create role problems and therefore resulting to stress for the individual employee in an organization. They include;

a) Responsibility for the work of others - Reconciling overlapping or conflicting objective of groups and organizations of groups and individuals, of self and superiors.

b) Innovative functions - Conflicting priorities and different psychological demands between the routine and administrative aspects of the job and the creative side.

c) Integrative or boundary functions - The particularly stressful role to the coordinator, link persons or outside contact, perhaps due to the lack of control over their demands or resources.

d) Relationship problems - Difficulties with a boss, subordinates or colleagues. For some people, particularly those with a technical orientation, the need to work with other people is a worrying complication.

e) Career uncertainty - If future career prospects become doubtful the uncertainty can quickly become stressful and spread to affect the whole of a person's work.

It is important to emphasis that, employees and managers of banking and manufacturing firms viewed the major source of stress as the incompetence of their superiors, poor internal communication, office politics, time pressures and deadlines, unrealistic business objectives, constant interruptions and securing access to the right information. This is a view from an empirical research findings conducted by the institute of management and personal performance consultants, UK limited (1993, December).

Stress is viewed as state of tension experienced by individuals facing extraordinary demands, constraints, or opportunities in a work environment. [24] Observed that stress has both negative and positive influence on the lives of employees. The two faces of stress can be termed as constructive stress and destructive stress. 
Defined constructive stress or eustress as acts in a positive way. It occurs at moderate stress levels by prompting increased work effort, stimulating creativity, and encouraging greater diligence. This stress may be known as the tension that causes you to study hard before examinations, pay attention, and complete assignments on time in a difficult class. Destructive stress or distress is a dysfunctional for both the individual and the organization. One form of it is "Job burnout" that shows itself as loss of interest in and satisfaction with a job due to stressful working conditions. [2] Noted that, when a person is "burned out" he or she feels exhausted, emotionally and physically, and thus unable to deal positively with work responsibilities and opportunities. Too much stress can overload and breakdown a person's physical and mental systems resulting in absenteeism, turnover, errors, accidents, dissatisfaction, reduced performance, unethical behavior and even illness. [2, 25] maintains that, the common typical symptoms of stress include;

- Excessive alcohol intake

- Tiredness

- Headaches

- High blood pressure

- Pounding heart

- Low energy

- Sleeping problems

- Aggression

- Feelings of inadequacy

- Hyperventilation

- Moodiness

- Inability to relax
- Temper tantrums

- Loss of concentration

- Excess worrying

- Heavy cigarette smoking

- Stomach upset and ulcers

-Irritability

- Anxiety

- Dizziness

- Bad breath

- Over eating

- Memory loss

Noted the importance of demonstrating a relationship between personality and health. Negative emotional states such as depression, hostility and anxiety appear to be linked to heart diseases, respiratory disorders such as asthma and headaches and ulcers. Health risks are greater where negative states are chronic, particularly where they are one an aspect of personality.

Maintains that, there are a number of other causes of stress that arise from individual factors: difficulty in coping with change, lack of confidence and assertiveness in relationships, poor time management, and poor stress management skills.

In an organizational context, typical stressors that are likely to emerge include;

i. Inadequate physical working environment - Noise, bad lighting, inadequate ventilation, lack of privacy, extremes of heat and cold, old and unsuitable and unreliable equipment.

ii. Inappropriate job design - Poor coordination, inadequate training, inadequate information, rigid procedures, inadequate staffing, excessive workloads, no challenge little use of skills, no responsibility or participation in decision making, role ambiguity.

iii. Poor management style - Inconsistent, competitive, crisis management, autocratic management, and excessive time pressures placed on employees.

iv. Poor relationships - With superiors, with colleagues, with particular individuals, lack of feedback, little social contact, racial and sexual harassment.

v. Uncertain future - Job insecurity, fear of unemployment or redeployment, few promotions, opportunities, low statue job.

vi. Divided loyalties - Conflicts between personal aspirations and organizational requirements, conflict between job and family and social responsibilities. 
It will be important to emphasis that stress can be exciting and arousing and can enhance our sense of satisfaction and accomplishment and lead to improve our performance. In this sense is "Eustress", used to describe positive aspect of stress. In contrasts, it will be distress, which means the unpleasant, debilitating and unhealthy side of stress. [23] Stress can be episodic. When dealing with life's problems, we get anxious, cope with the problem, and then relax again. Some events can be extremely stressful, such as the death of a close relative or a term in prison. Other experiences can also be stressful, such as getting a poor examination grades, being fired for speeding, or arguing with a parent, but trigger a less extreme response. Each of these episodes on its own is unlikely to cause lasting damage. However, when several of these episodes occur around the same time, the health risk is increased.

Stress can be chronic. This happens when employee face constant stress, with no escape and can lead to exhaustion and burnout. This may be due to the unfortunate coincidence of several unrelated episodes. However, chronic stress also arises from the enduring features of our personal, social and organizational circumstances. In situation where we are faced with been under pressure, always facing multiple and unrealistic demands, always having difficulties with our work, our colleagues and our relationships, then the health risk from stress is likely to increase.

The working environment, the crowded responsibilities, schedules and demanding expectations from bank customers have always placed strenuous demands on bank workers in a bid to carry out their work task inorder to attain goals of the banking firms. This has caused exhaustion, tiredness, anxiety, aggression, feeling of inadequacy, headaches, and moodiness to employee, causing havoc and devastation situation to banking firm. Devising effective management strategies to curb the devastating effect of stress in bank has been a problem to contend with by bank management. Infact if not properly managed, it will affect profit attainment and high performance trends of the banks. The researcher is therefore interested to empirically search for viable strategies manager will use to address this epidemic.

\section{RESEARCH PROBLEM}

There exist instances of job dissatisfaction, job burnout, high blood pressures, tensions, anxiety, irritability, boredom, procrastination among employees leading to low performance output and trends in banking firms in Nigeria. In most cases these have resulted to absenteeism to work by employees and high job turnover. The demanding nature of the banking tasks have called for a critical diagnosis to establish whether responsibilities and tasks assigned to bank officers is over demanding leading to role incompatibility, role ambiguity, role overload and role under-load, creating anxiety, frustration, anger, depression, hostility amongst staff, hence the epidemic symptoms are usually stressful to employee. The concern is therefore to establish how chief executive officers of bank have put in place management strategies to tackle the mess of stress which if not effectively addressed will affect performance of the organization.

\section{OBJECTIVES OF THE STUDY}

i. To determine the extent to which the strategies for management of stress will impact on the performance of the commercial banking firms in Nigeria.

ii. To evaluate the extent to which the consequences of stress will affect the performance output of employees of the commercial banking firms in Nigeria.

\section{RESEARCH QUESTIONS}

i. To what extent have the strategies for management of stress impacted on the performance of the commercial banking firms in Nigeria? 
ii. To what extent have the consequences of stress affected the performance output of employees of the commercial banking firms in Nigeria?

\section{RESEARCH HYPOTHESES}

H01: Strategies for management of stress have not significantly impacted on the performance of the commercial banking firms in Nigeria.

H02: The consequences of stress have no effect on the performance output of employees of the commercial banking firms in Nigeria.

\section{REVIEW OF RELATED LITERATURE}

View stress as a dynamic condition in which an individual is confronted with an opportunity, constraint, or demand related to what he or she desires and for which the outcome is perceived to be both uncertain and important. Constraint is viewed as the forces that prevent individuals from doing what they desire while demand is the loss of something desired.

Noted that one potential major source of work stress arises from role incongruence and role conflict. Role incongruence arises when a member of staff is perceived as having a high and responsible position in one respect but a low standing in another respect. Difficulties with role incongruence can arise from the nature of grouping and formal relationships within the structure of the organization. For example, there are a number of work related relationships, such as doctor and nurse or senior manager and personal assistant, which can give rise to a potential imbalance of authority and responsibility.

See role conflict as arising from inadequate or inappropriate role definition and needs to be distinguished from personality clashes. These arise from incompatibility between two or more people as individuals even through their roles may be defined clearly and understood fully. [21] Observed that, in practice, the manner in which a person actually behaves may not be consistent with their expected pattern of behaviours. This inconsistency may be a result of role conflict. He further stressed that, role conflict can include;

i. $\quad$ Role incompatibility

ii. Role ambiguity

iii. Role overload

iv. Role under-load

Role incompatibility - arises when a person faces a situation in which simultaneous different or contradictory expectations creates inconsistency. Compliance with one set of expectations makes it difficult or impossible to comply with other expectations. The two role expectations are in conflict. A typical example concerns the person "in the middle", such as the supervisor or section head, who faces opposing expectations from workers and from management. Another example, might be the situation of a manager who believes in a relaxed participative style of behavior more in keeping with a theory Y approach, but who's superior believes in a theory X approach and expects the manager to adopt a more formal and directive style of behavior. This can cause stress.

Role ambiguity - This occurs when there is lack of clarity as to the precise requirements of the role and the person is unsure what to do. The person's own perception of their role may be differ from the expectation of others. This implies that insufficient information is available for the adequate performance of the role. Role ambiguity may result from a lack of formally prescribed expectations. It is likely to arise in large, diverse groups or at times of constant change. Uncertainty often relates to such matters as the method of performing tasks, the extent 
of the person's authority and responsibility, standards of works, and the evaluation and appraisal of performance.

Role overload - This occurs when a person faces too many separate roles or too great a variety of expectations. The person is unable to meet satisfactorily all expectation and some must be neglected in order to satisfy others. This leads to conflict of priority. Role overload can be seen in terms of the total role set and implies that the person has too many separate roles to handle. This may cause stress to the employee.

Role under-load - This can arise when the prescribed role expectations fall short of the persons own perception of their role. The person may feel their role is not demanding enough and that they have capacity to undertake a larger or more varied role, or an increased number of roles. Role under-load may arise, for example, when a new member of staff is first appointed or from the initial effects of delegation.

Defined stress as an adaptive response mediated by individual characteristics and/or psychological processes. In other words, it is a consequence of any external action, situation or event that places special, physical and or psychological demand on the person. Stressors are the wide variety of things that cause stress for individuals. Some of the stressors can be traced directly to what people experience in the workplace; where as other derives from non-work place and personal factors. In another way, stressors can be grouped as individual level stressor, group level stressors, organizational stressor, and extra organizational stressors [25].

Work Stressors - These can arise from many sources, from excessively high or low task demands, role conflict s or ambiguities, poor interpersonal relations or carrier progress that is either too slow or too fast. A list of common stressors include the following;

i. Task demands - When an employee is asked to do too much or being asked to too little.

ii. Role ambiguities - Not knowing what one is expected to do or how work performance is evaluated.

iii. Role conflicts - Feeling unable to satisfy multiple, possibly conflicting, performance expectations.

iv. Ethical dilemmas - Being asked to do things that violate the law or personal values.

v. Interpersonal problems - Experiencing bad relationships or working with others with whom one does not get along.

vi. Career developments - Moving too fast and feeling stretched, moving too slowly and feeling stock in a plateau.

vii. Physical setting - Being bothered by noise, lack of privacy, pollution, or other unpleasant working conditions.

Life Stressors - A less obvious, though important source of stress for people at work is the "spillover effect" that results when forces in their personal lives "spill-over" to affect them at work such life stressors as family events (e.g the birth of a new child, economic difficulties, the sudden loss of a big investment) and personal affairs (e.g a separation or divorce) can all be extremely stressful. Since is often difficult to completely separate work and non-work lives, life stressors can affect the way people feel and behave on their job as well as in their personal lives.

Another set of stressors include personal factors such as individual needs, capabilities and person ability. Stress can reach a destructive state more quickly for example when experienced by highly emotional people or by those with low self-esteem. People who perceived a good fit between job requirements and personal skills secures to have a higher tolerance for stress 
than do those who feel less incompetent as a result of a person-job mismatch. Additionally, aspect of personality such as achievement orientation, impatience, and perfectionism of individual with type a personalities for example, often create stress for them in work setting that others find relatively stress free. Another classification of stressor proffered by [23] is as follows;

i. Individual level stressors: - There are directly associated with a person's job duties e.g work overload, role ambiguity, role conflict, personal economic problems, and inherent personality characteristics.

ii. The Group-level stressors: - There are caused by group dynamics and managerial behavior, conflict power tussle and politics in organization. Managers create stress for employee by exhibiting inconsistent behavior by refusal to provide support, lack of concern for the employee, laying too much emphasis on high productivity, focusing on negatives while ignoring good performance.

iii. Organizational stressor: - These can affect large number of employees. These include the overriding management style, organizational leadership, task demands, role demands, interpersonal demand climate of the organization. The office designs and general office can induce stressful working condition if not adequately catered for. Empirical research has demonstrated that poor lighting, loud noise, improper placement of furniture, inadequate space and dirty or smelling environment can create stressful situation.

iv. Extra organizational stressor: - These types are caused by factors outside the organization. It range from factors such as balancing one's career and family life to one's socio economics status to political and economic instability, lack of mobility. Stress is quite higher for people with lower socio economics status. Status represents a combination of economic factors measured by income, social factor as measured by educational level, work status as indexed by one's type of occupation, [25].

\section{CONSEQUENCES OF STRESS}

$[12,23,25]$ in their different empirical research effort revealed that stress manifest in a number of ways in different individuals. An individual may develop high blood pressure, ulcer, irritability, conjunctivitis, exhaustion, and loss of appetite and eventually it may lead to accident as well. These manifest symptoms or consequences can be grouped into three (3) categories. These are:-

i. Physiological symptoms:- Here stress quite often creates change in metabolism, increase heart and breathing rates, increase blood pressure, bring on headaches, induce heart attacks and create aguish in employee.

ii. Psychological symptoms: - Stress can cause dissatisfaction. Job related stress can cause job related dissatisfactions. Infact job dissatisfaction is the simplest and most obvious psychological effect of stress. The simplest symptom revealing in this case include tension, anxiety, irritability, boredom and procrastination.

iii. Behavioural symptoms:- The behavioral related stress symptoms include changes in productivity, absence and turnover, as well as change in eating habits, increased smoking or consumption of alcohol, rapid speech, fidgeting and sleep disorders, insomnia. The major significant research study in stress performance relationship is the inverted U relationship.

The logic underlying the inverted $\mathrm{U}$ is that low to moderate levels of stress stimulate the body and increase its ability to react. Individuals then often perform their task better, more intensely or more rapidly. But too much stress places unattainable demands or constraints on a person, which result in lower performance. This inverted U pattern may also describe the 
reaction to stress over time, as well as to changes in stress intensity. That is, even moderate levels of stress can have a negative influence on performance over the long term as the continued intensity of the stress wears down the individual and saps his or her energy resources. In a nutshell, the longer time a stressful situation last, the poorer the performance as the continued intensity of the stress wears down the individual.

\section{Inverted - $\mathrm{U}$ relationship between stress and job performance}

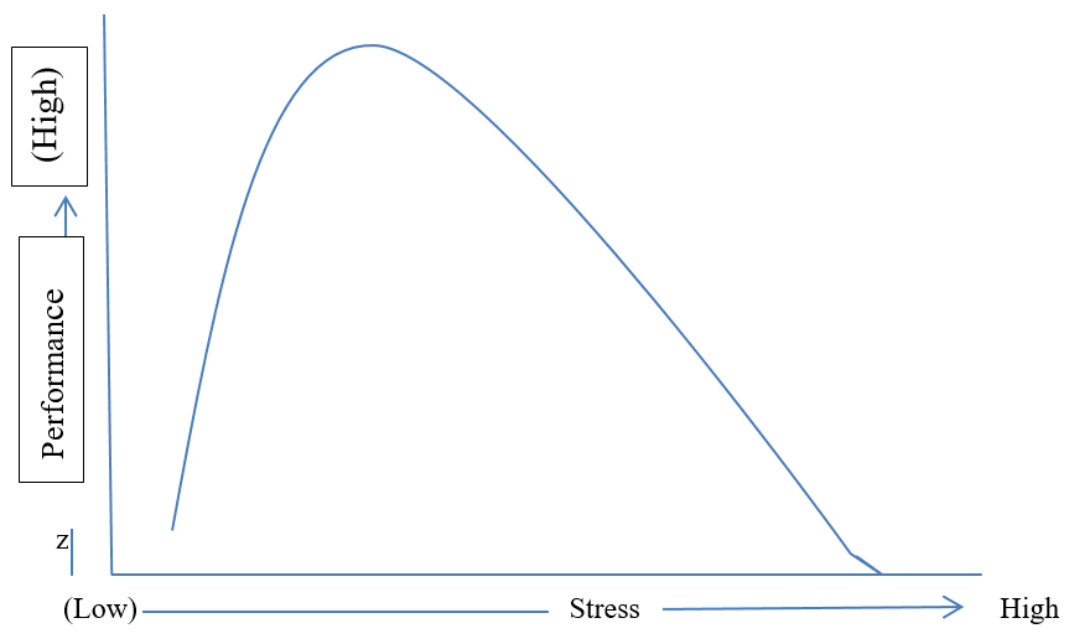

Another consequence of stress is burnout a feeling of exhaustion that can develop when someone experience too much stress for an extended period of time. Burnout results in constant fatigue, frustration, and helplessness increased rigidity follows, as does a loss of selfconfidence and psychological withdrawal. The individual dreads going to work, often puts in longer hours but get less accomplished than before, and exhibits mental and physical exhaustion. Because of the damaging effects of burnout, some firms are taking steps to help avoid it. For example, British Airways provides all of its employee with training designed to help them recognized the symptoms of burnout and develop strategies to avoid them [12]. Nigerian banking firms have also adopted this style of managing the stress syndrome for a productive result.

\section{STRATEGIES FOR MANAGING STRESS BY ORGANIZATIONS}

Given the devastating nature of stress and accompany consequences associated with it, managers of organization needs to device ways and strategies for its effective management in order to derive quality performance of the organization. [12, 2, 23, 25, 7] suggested various ways of managing stress in organizations. These are;

Emotional - focused strategies which improve individual resilience and coping skills. These include;

i. $\quad$ Consciousness - Rising to improve self-awareness.

ii. Exercise and fitness programmes.

iii. Self-help training, in bio feedback, meditation, relaxation, coping strategies.

iv. Time management training

v. Development of other social and job interests.

Problem - focused strategies deal directly with the stressors and include;

i. Improved selection and training mechanisms.

ii. Staff counseling programmes.

iii. Improved organizational communication. 
iv. Job redesigned and enrichment strategies.

v. Development of team working systems.

Identified the most and least stressful jobs as follows;

\section{Ten most stressful Jobs}
1. Inner-city high school teacher
2. Police officer
3. Miner
4. Air traffic controller
5. Medical intern
6. Stockbroker
7. Journalist
8. Customer-service/compliant worker
9. Secretary
10. Waiter

$\bigcirc$

They emphasized that; an employee can take personal responsibility for reducing his or her stress level. Individual strategies that have proven effective include time management techniques, physical exercise, relaxation techniques and a close social support network. [15].

Time Management - Many people manage their time poorly. The thing we have to accomplish in any given day or week are not necessarily beyond completion if we manage our time properly. The well-organized employee, like the well-organized student, can often accomplish twice as much as the person who is poorly organized. So understanding and using basic time management principles can help individuals cope better with tensions created by job demands. A few of the well-known time management principles are:-

a) Making daily lists of activities to be accomplished.

b) Prioritizing activities by importance and urgency

c) Scheduling activities according to the priorities set and

d) Knowing you daily cycle and handling the most demanding parts of your job during the high part of your cycle, when you are most alert and productive.

Physical Activity - Non-competitive physical exercise, such as aerobics, walking, jogging, swimming, and riding a bicycle, has long been recommended by physicians as a way to deal with excessive stress levels. These forms of physical exercise, increase heart capacity, lower atrest heart rate, provide a mental diversion form work pressures, and offer a means to "let off steam".

Relaxation Techniques - Here individuals can teach themselves to reduce tension through relaxation techniques such as mediation, hypnosis, and biofeedback. The objective is to reach a state of deep relaxation, where you feel physically relaxed, since what detached from the immediate environment and detached from body sensation. Empirical evidence revealed that, 15 to 20 minutes a day of deep relaxation release tension and provides a person with a pronounced sense of peacefulness. Importantly, significant changes in heart rate, blood pressure, and other physiological factor result from achieving the deep relaxation condition. 
Building social support: - Having friends, family, or colleague to talk to provide an outlet when a stress level becomes excessive. Expanding your social support network, therefore, can be a means for tension reduction. It provides you with someone to listen to your problems and too often a more objective perspective on the situation. Other organizational approaches or strategies may include; improved processes for choosing employees, placement of employee in appropriate jobs, realistic goal setting, designing jobs with employee needs and skills in mind, increased employee involvement, improved organizational communication, offering employee sabbaticals and establishing of corporate wellness programs, creating jobs that give employees more responsibility, more meaningful work, more autonomy and increased feedback can reduce stress because these factors give the employee greater control over work activities and lessen dependence on others. All these strategies can help curb menace of stress in organization.

\section{METHODOLOGICAL FRAMEWORK}

A total of 398 questionnaires were distributed to employees of 21 commercial banking firms in Nigeria. The research design technique adopted was quasi-experimental which place premium on survey sample. The population for this study comprises of 21 licensed commercial banks employee in Nigeria operational as at December, 2016. All the categories of staff are considered in the research. The employee population in details in the 21 commercial banks is stated as follows:- Access Bank Plc, 800, Diamond Bank Plc, 4568, Eco Bank Nigeria Plc, 2410, Enterprise Bank Ltd, 1120, Fidelity Bank Plc, 2120, First Bank of Nigeria Plc, 6610, Firstcity Monumental Bank Plc (FCMB), 2000, Guarantee Trust Bank plc (GTB), 10000, Heritage Banking Company Ltd (HBCL), 657, Keystone Bank Ltd, 2233, Mainstream Bank Ltd, 2250, Sky Bank Plc, 821, Stanbic IBTC Holding Plc, 2077, Standard Chartered Plc, 1220, Sterling Bank Plc, 3034, Union Bank Nigeria, 6210, Wema Bank Plc, 1317, Zenith Bank Plc 6616, Jaiz Bank Plc 525. These all together make a total employee population size of 64,846 . (Annual statement and Account reports of various commercial banks, 2010).

This selection will enable us study the commercial banking firm base on size (i.e bigger, moderate and smaller in size), age and asset base, quality and scope of operations. The choice of these banks employed the use of disproportionate stratified sampling technique in which the banks are classed into three (3) strata.

The first category of commercial banking firms is bigger in size in terms of employees, scope of operations and asset base. They have population of staff above 3500 .

The second category of banking organization is moderately bigger in size in terms of employee, scope of operations and assets base. They have (staff/employee) population of between 20003449.

The third category banking of firms is smaller in size in terms of employee, scope of operation and asset base. They have (staff/employee) population below 2000.

Both primary and secondary sources of data are used. The primary sources of data collection employed the use of questionnaire using 5-point likert rating scale questionnaire of strongly Agree (SA), Agree (A), Undecided (U), Disagree (D) and strongly Disagree (SD) is administered to obtain viable information on the subject matter of stress management strategies by commercial banking firms in enhancing employee performance in the Nigerian commercial banking firms. 
To scientifically generate a sample size, the [26] formula was applied. According to [1] this formula can be used for a homogeneous population like the one in this research.

The formula is stated below;

Where $n=$ Sample size

$$
n=\frac{N}{1+N(e)^{2}}
$$

$1=$ Constant value

$\mathrm{N}=$ Population size

$\mathrm{e}=$ Porportion of sampling error in a given situation. The researcher assumed $95 \%$ confidence level having $5 \%$ to error.

In this case, the total population size of 64,846 was used to obtain the sample size of twenty one (21) commercial banking firms in the study at 0.05 level of significance or $5 \%$ margin of error as shown below;

$$
\begin{aligned}
& n=\frac{64,846}{1+64,846(0.05)^{2}} \\
& n=\frac{64,846}{1+64,846(0.0025)}
\end{aligned}
$$

$n=398$ This is the total sample size for the research.

From the total sample size, the individual commercial banking organization sample size is obtained. The formula adopted in this case is Bowley's allocation formula (1964) in [] as shown below;

$$
n h=\frac{n N h}{N}
$$

Where $n h=$ the number of units allocated to each banking firm.

$\mathrm{n}=$ total sample size

$\mathrm{NH}=$ the number of employees in each banking firm.

$\mathrm{N}=$ the population size

Following the Bowley's allocation formula, the respective commercial banking sample size is determined as shown below;

For Guarantee Trust Bank plc

$$
\text { For Zenith Bank plc } \quad n h=\frac{398 \times 6616}{64,846}
$$

$$
\begin{aligned}
& n h=\frac{398 \times 10,000}{64,846} \\
& n h=61
\end{aligned}
$$

The procedure is applicable for the rest of the banks. 
Table 1.0 Number of Commercial banks based on classification and allocation of sample size to each commercial bank

\begin{tabular}{|c|c|c|c|}
\hline S/NO & Name of Commercial Bank & $\begin{array}{l}\text { Population of } \\
\text { staff/employee }\end{array}$ & Selected sample size \\
\hline \multicolumn{4}{|c|}{$\begin{array}{l}\text { The first category of commercial banking firms (employee/staff size above } 3000 \text {, bigger in size in terms of } \\
\text { employees, scope of operations and Assets base). }\end{array}$} \\
\hline $\begin{array}{l}1 . \\
2 . \\
3 . \\
4 . \\
5 . \\
6 .\end{array}$ & $\begin{array}{l}\text { Guarantee Trust Bank plc (GTB) } \\
\text { Zenith Bank Plc } \\
\text { First Bank Plc } \\
\text { Union Bank (Nigeria) } \\
\text { United Bank for Africa (UBA) Plc } \\
\text { Diamond Bank Plc }\end{array}$ & $\begin{array}{l}10000 \\
6616 \\
6610 \\
6210 \\
5561 \\
4568\end{array}$ & $\begin{array}{l}61 \\
41 \\
41 \\
38 \\
35 \\
28\end{array}$ \\
\hline \multicolumn{4}{|c|}{$\begin{array}{l}\text { Second category of commercial banking firms (employee/staff size between } 2000-3499 \text {, moderately bigger in } \\
\text { size in terms of employees, scope of operations and Assets base). }\end{array}$} \\
\hline $\begin{array}{l}7 . \\
8 . \\
9 . \\
10 . \\
11 . \\
12 . \\
13 . \\
14 .\end{array}$ & $\begin{array}{l}\text { Sterling Bank plc } \\
\text { Eco Bank Nigeria } \\
\text { Mainstream Bank Ltd } \\
\text { Keystone Bank Ltd } \\
\text { Fidelity Bank Plc } \\
\text { Stanbic IBTC Holding Plc } \\
\text { First City Monumental Bank Ltd } \\
\text { Unity Bank Plc }\end{array}$ & $\begin{array}{l}3034 \\
2410 \\
2250 \\
2233 \\
2120 \\
2077 \\
2000 \\
2072\end{array}$ & $\begin{array}{l}19 \\
15 \\
14 \\
14 \\
13 \\
13 \\
13 \\
13\end{array}$ \\
\hline \multicolumn{4}{|c|}{$\begin{array}{l}\text { Third category of commercial banking firms (employee/staff size below } 2000 \text { smaller in size in terms of } \\
\text { employees, scope of operations and Assets base). }\end{array}$} \\
\hline $\begin{array}{l}15 . \\
16 . \\
17 . \\
18 . \\
19 . \\
20 . \\
21 .\end{array}$ & $\begin{array}{l}\text { Standard Chartered Bank plc } \\
\text { Wema Bank Plc } \\
\text { Enterprise Bank Limited } \\
\text { Access Bank Plc } \\
\text { Sky Bank Plc } \\
\text { Heritage Banking Company Ltd. } \\
\text { Jaiz Bank Plc }\end{array}$ & $\begin{array}{l}1220 \\
1317 \\
1120 \\
900 \\
821 \\
657 \\
525\end{array}$ & $\begin{array}{l}7 \\
8 \\
7 \\
6 \\
5 \\
4 \\
3\end{array}$ \\
\hline
\end{tabular}

Source: Commercial banking firms record and field survey, 2016.

\section{FACTOR AND RELIABILITY ANALYSIS}

Confirmatory factor analysis with Varimax rotation has been performed to examine whether the classification of the variables into the specific factors is valid or not. In this case the individual approaches, organizational approaches/strategies for managing stress and consequences of stress as affecting performance output of employee is subjected to analysis. KMO (Kaiser-Meyer-Olkin) is used to measure the sampling adequacy, accepting a weak threshold (0.5) (Malhotra, 1999) and Bartlett test of sphericity is also adopted. The total variance explained (TVE) score is also used to measure how data is distributed within a range and also how much the response differs (accepted threshold, 0.6). Further, Cronbach Alpha ( $\alpha$ ) reliability test has been performed to assess internal consistency of measurement adopting the weak threshold 0.6 [22, 8, and 3]. 
Table 3: Factor Analysis

\begin{tabular}{|c|c|c|c|c|}
\hline Factors & Statistics & $\begin{array}{l}\text { Strategies for managing stress } \\
\text { (Items) }\end{array}$ & Loading & $\begin{array}{l}\text { No } \\
\text { of } \\
\text { item } \\
\text { s }\end{array}$ \\
\hline $\begin{array}{l}\text { Individual } \\
\text { Approaches/Strat } \\
\text { egies }\end{array}$ & $\begin{array}{l}\text { K.M.O. }=0.509 \\
\text { Sig }=0.00 \\
\text { (TVE) }=0.455 \\
\text { Cronbach Alpha() } \\
=0.929 \\
\text { Bertlett's test of } \\
\text { Sphereity } \\
\text { Approx. Chi } \\
\text { square }=26.82 \\
\text { Df }=28 \\
\text { Sig. }=0.00\end{array}$ & $\begin{array}{l}\text { 1) Adoption of Time management principles is essential } \\
\text { for stress management. } \\
\text { 2) Making daily lists of activities to be accomplished is } \\
\text { essential principle. } \\
\text { 3) Prioritizing activities by importance and urgency is } \\
\text { necessary. } \\
\text { 4) Scheduling activities according to priorities set is } \\
\text { important. } \\
\text { 5) Knowing your daily cycle and handling most } \\
\text { demanding part is important. } \\
\text { 6) Physical activity i, e Noncompetitive physical } \\
\text { exercise such as aerobics, walking, jogging, } \\
\text { swimming and riding bicycle is necessary. } \\
\text { 7) Relaxation techniques are essential for stress } \\
\text { management. } \\
\text { 8) Building social support i.e. having friends, family or } \\
\text { colleague to talk to is necessary. }\end{array}$ & $\begin{array}{l}0.905 \\
0.819 \\
\\
0.888 \\
0.788 \\
0.830 \\
\\
0.760 \\
\\
\\
0.867 \\
0.836\end{array}$ & 8 \\
\hline Factors & Statistics & $\begin{array}{l}\text { Strategies for managing stress } \\
\text { (Items) }\end{array}$ & Loading & $\begin{array}{l}\text { No } \\
\text { of } \\
\text { item } \\
\text { s }\end{array}$ \\
\hline $\begin{array}{l}\text { Organizational } \\
\text { Approaches/Strat } \\
\text { egies }\end{array}$ & $\begin{array}{l}\text { K.M.O. }=0.533 \\
\text { Sig }=0.00 \\
\text { (TVE) }=0.472 \\
\text { Cronbach Alpha() } \\
=0.907 \\
\text { Bertlett's test of } \\
\text { Sphereity } \\
\text { Approx. Chi } \\
\text { square }=22.76 \\
\text { Df }=21 \\
\text { Sig. }=0.00\end{array}$ & $\begin{array}{l}\text { 1) Redesigning jobs to give employees more } \\
\text { responsibility, more meaningful work, more } \\
\text { autonomy and increased feedback reduces stress. } \\
\text { 2) Increases formal organizational communications with } \\
\text { employees reduce uncertainty. } \\
\text { 3) Placement of employees in appropriate Jobs reduces } \\
\text { stress. } \\
\text { 4) Setting realistic organizational goal is a strategy for } \\
\text { stress management. } \\
\text { 5) Increased employee involvement helps to reduce } \\
\text { stress. } \\
\text { 6) Offering employee sabbaticals and establishment of } \\
\text { corporate wellness programs reduce stress. } \\
\text { 7) Flexible work time is a strategy for stress } \\
\text { management. }\end{array}$ & $\begin{array}{l}0.865 \\
0.784 \\
0.863 \\
0.804 \\
0.777 \\
0.709 \\
0.802\end{array}$ & 7 \\
\hline $\begin{array}{l}\text { Consequences of } \\
\text { Stress }\end{array}$ & $\begin{array}{l}\text { K.M.O. }=0.495 \\
\text { Sig }=0.00 \\
\text { (TVE) }=0.461 \\
\text { Cronbach Alpha() } \\
=0.935 \\
\text { Bertlett's test of } \\
\text { Sphereity } \\
\text { Approx. Chi } \\
\text { square }=31.51 \\
\text { Df }=36 \\
\text { Sig. }=0.00\end{array}$ & $\begin{array}{l}\text { 1). Unrealistic business objectives lead to anxiety. } \\
\text { 2). Poor internal communication result to frustration. } \\
\text { o 3). Office politics can cause stress. } \\
\text { 4). Time pressures and deadlines result to stress. } \\
\text { 5). Attending too many meetings is stressful. } \\
\text { 6). In competent senior management leads to } \\
\text { depression. } \\
\text { 7). Poor relationship between colleagues can result to } \\
\text { hostilities and stress. } \\
\text { 8). Constant interruptions can lead to stress. } \\
\text { 9). Managing staff problems can be burdensome and } \\
\text { threatening. }\end{array}$ & $\begin{array}{l}0.870 \\
0.776 \\
\\
0.849 \\
0.776 \\
0.834 \\
0.797 \\
\\
0.890 \\
\\
\\
0.700 \\
0.850\end{array}$ & 9 \\
\hline
\end{tabular}


Table 4.0 KMO and Bartlett's Test

\begin{tabular}{|l|l|l|}
\hline \multicolumn{2}{|l|}{ Kaiser-Meyer-Olkin Measure of Sampling Adequacy. } & 0.512 \\
\hline \multirow{2}{*}{ Bartlett's Test of Sphericity } & Approx. Chi-Square & \\
& & 27.03 \\
\cline { 2 - 3 } & Df & 28 \\
\cline { 2 - 3 } & Sig. & 0.001 \\
\hline Overall Reliability Statistics : Cronbach's Alpha & $\mathbf{0 . 9 2 4}$ \\
\hline
\end{tabular}

KMO \& Bartlett's Test of Sphericity is a measure of sampling adequacy that is recommended to check the case to variable ratio for the analysis being conducted. Also, the Bartlett's Test of Sphericity relates to the significance of the study and thereby shows the validity and suitability of the responses collected to the problem being addressed through the study. We can see that we have good values for all variables for the MSA but the overall value is a bit low at 0.512 , however Bartlett's Test of Sphericity has an associated P value (sig in the table) of $<0.05$ as by default SPSS reports p values of less than 0.05 as 0.001 , So from the above results we know that we can now continue and perform a valid factor analysis. It can also be seen that individual approaches/strategies, organizational approaches and consequences of stress amongst others were subjected to reliability test using Cronbach's Alpha but in all cases it was high.

The SPSS analysis gives us Cronbach's Alpha values for individual approaches/strategies, organizational approaches and consequences of stress amongst others as shown in the above table. This is an indication that our instruments are reliable. According to Everitte (2006), an alpha value of less than 0.60 is unacceptable; $0.60-0.65$ is undesirable, $0.65-0.70$ is minimally acceptable; $0.70-0.80$ is respectable; $0.80-0.90$ is very good and more than 0.90 means consider shortening the scale by reducing the number of items. As it is for all the banking firms under survey it shows that, the instrument is very reliable, hence our overall reliability statistics: Cronbach Alpha is 0.924. Multiple regression test is adopted for the testing formulated hypotheses. 


\section{DATA PRESENTATION AND ANALYSIS:}

Table 1.0 Respondent views concerning strategies adopted by commercial banking firms for managing stress such as Individual Approaches and Organizational Approaches in Nigeria

\begin{tabular}{|c|c|c|c|c|c|c|c|}
\hline \multirow[t]{2}{*}{ Statement } & \multirow{2}{*}{$\begin{array}{l}\text { Respondent } \\
\text { category }\end{array}$} & \multicolumn{6}{|c|}{ Degree of Response } \\
\hline & & SA & $\mathrm{A}$ & $\mathrm{U}$ & $\mathrm{D}$ & SD & Total \\
\hline $\begin{array}{l}\text { The strategies adopted by commercial banking } \\
\text { firms for managing stress of employee include }\end{array}$ & $\begin{array}{ll}\text { Top } & \text { level } \\
\text { Management } & \end{array}$ & 43 & 19 & 2 & 4 & 2 & 70 \\
\hline $\begin{array}{l}\text { individual approaches (i.e time management, } \\
\text { e.g. Prioritizing activities, making daily list of }\end{array}$ & $\begin{array}{ll}\text { Middle } & \text { level } \\
\text { Management } & \end{array}$ & 74 & 40 & 4 & 5 & 5 & 128 \\
\hline $\begin{array}{l}\text { activities, scheduling activities according to } \\
\text { importance and urgency, knowing your daily }\end{array}$ & $\begin{array}{ll}\text { Lower } & \text { level } \\
\text { Management } & \end{array}$ & 120 & 60 & 5 & 6 & 8 & 199 \\
\hline $\begin{array}{l}\text { cycle, physical exercise 1.e. walking, jogging, } \\
\text { swimming, relaxation techniques, building } \\
\text { social support, placement of employee in } \\
\text { appropriate jobs, realistic goal settings, } \\
\text { designing jobs with employee needs and skills } \\
\text { in mind, improvement in organizational } \\
\text { communication and establishment of corporate } \\
\text { wellness programs). }\end{array}$ & Total & 237 & 119 & 11 & 16 & 15 & 398 \\
\hline
\end{tabular}

\section{Source: Field survey (2016).}

The data shown in Table 1.0 above, clearly revealed that strategies adopted by commercial banking firms for managing stress for employees include individual approaches such as time management by prioritizing activities, scheduling activities according to importance and urgency, making daily list of activities, knowing your daily cycle, physical exercise by employee by way of swimming, jogging, walking, relaxation techniques, building social support, placement of employee in appropriate jobs, realistic goal settings, designing jobs with employee needs and skills in mind, improvement in organizational communication amongst others.

In fact 237 of 398 representing $59.54 \%$ of the respondent strongly agree on the notion. About 119 out of $398(29.89 \%)$ agree on this position, 11 out of $398(2.76 \%)$ were undecided on the issue of managing stress.16 out of 398 representing (4.02\%) disagree and finally 15 out of 398(or 3.76\%) strongly disagree on this notion. On the whole one can derive that, there is overwhelming response that Nigerian commercial banking firm adopt several strategies to manage the menace of stress in order to have a productive organization. 
Table 2.0 Respondent opinion pertaining how strategies for managing stress have enhanced performance goal attainment in commercial banking firms Nigeria

\begin{tabular}{|c|c|c|c|c|c|c|c|}
\hline \multirow[t]{2}{*}{ Statement } & \multirow{2}{*}{$\begin{array}{l}\text { Respondent } \\
\text { category }\end{array}$} & \multicolumn{6}{|c|}{ Degree of Response } \\
\hline & & SA & $\mathrm{A}$ & $\mathrm{U}$ & $\mathrm{D}$ & SD & Total \\
\hline \multirow{4}{*}{$\begin{array}{l}\text { Effective application of strategies for managing } \\
\text { stress such as time management strategies, } \\
\text { relaxation strategies, jogging, swimming, } \\
\text { designing jobs with employee needs and skills, } \\
\text { placement of employee in appropriate jobs, } \\
\text { realistic goal settings, increase organizational } \\
\text { communication, corporate wellness programs } \\
\text { amongst others have enhanced performance } \\
\text { goal attainments of banking firms in Nigeria. }\end{array}$} & $\begin{array}{ll}\text { Top } & \text { level } \\
\text { Management } & \end{array}$ & 47 & 19 & 2 & 2 & 3 & 73 \\
\hline & $\begin{array}{ll}\text { Middle } & \text { level } \\
\text { Management } & \end{array}$ & 75 & 44 & 2 & 3 & 2 & 126 \\
\hline & $\begin{array}{ll}\text { Lower } & \text { level } \\
\text { Management } & \end{array}$ & 127 & 64 & 2 & 4 & 2 & 199 \\
\hline & Total & 249 & 127 & 6 & 9 & 7 & 398 \\
\hline
\end{tabular}

Source: Field survey (2016).

The table above 2.0 revealed the respondent opinion pertaining how strategies for managing stress such as time management strategies, relaxation strategies, jogging, swimming, designing of employee jobs to meet skills and needs, placement of employee on appropriate jobs, realistic goal settings, increase organizational communication, corporate wellness programs amongst others can facilitate and enhanced performance goal attainments of commercial banking firms in Nigeria.

Overwhelmingly, 249 out of 398 (or $62.56 \%$ ) strongly agree that these strategies mentioned above were effectively applied and have led to productive goal attainment of profit, growth, survival etc. 127 out of 398 (31. 90\%) also agree on the subject matter. 6 out of $398(1.50 \%)$ were undecided on the issue. 9 out of 398 representing (2.26\%) disagree and finally 7 out of 398 representing $1.75 \%$ strongly disagree on the fact that, they are not aware of the application of stress management strategies in enhancing performance outcome of the banking firms in Nigeria.

\section{Hypothesis 1}

H01: Strategies for Management of stress have not significantly impacted on the performance of the commercial banking firms in Nigeria

\begin{tabular}{|l|r|r|r|r|}
\hline Model & \multicolumn{1}{|c|}{ Model Summary } \\
\hline 1 & $.839^{\mathrm{a}}$ & .704 & $\begin{array}{c}\text { Adjusted R } \\
\text { Square }\end{array}$ & $\begin{array}{c}\text { Std. Error of the } \\
\text { Estimate }\end{array}$ \\
\hline
\end{tabular}

The value of 0.839 indicates Strategies for Management of stress have significantly impacted on the performance of the commercial banking firms in Nigeria. The R square is the coefficient of determination which is 0.704 with $70.4 \%$ proportion of variance in the dependent variable. 
ANOVAa

\begin{tabular}{|rl|r|r|r|r|r|}
\hline Model & & Sum of Squares & df & Mean Square & F & Sig. \\
\hline \multirow{2}{*}{1} & Regression & 8.733 & 6 & 1.455 & 13.098 & $.000^{\mathrm{b}}$ \\
& Residual & 3.667 & 33 & .111 & & \\
& Total & 12.400 & 39 & & & \\
\hline
\end{tabular}

The table shows that the independent variables are statistically significantly, $F(6,33)=$ 13.098, $\mathrm{P}<0.05$. We reject the hypothesis which states that Strategies for Management of stress have not significantly impacted on the performance of the commercial banking firms in Nigeria.

a. Dependent Variable: Performance of Commercial Bank

Interpretation.

$\mathrm{y}=\mathrm{X} 1+\mathrm{X} 2+\mathrm{X} 3+\mathrm{X} 4+\mathrm{X} 5+\mathrm{X} 6$ where $\mathrm{C}$ is the constant.

Predicted $\mathrm{y}=0.233 \mathrm{X} 1+0.136 \mathrm{X} 2+0.285 \mathrm{X} 3+0.049 \mathrm{X} 4+0.021 \mathrm{X} 5+0.083 \mathrm{X} 6+1.188$

Strategies for Management of stress have a positive relationship on the performance of the commercial banking firms in Nigeria.

Table 3.0 Respondent opinion concerning the consequence of stress as having negative effect on the performance output of employees in commercial banking firms in Nigeria

\begin{tabular}{|c|c|c|c|c|c|c|c|}
\hline \multirow[t]{2}{*}{ Statement } & \multirow{2}{*}{$\begin{array}{l}\text { Respondent } \\
\text { category }\end{array}$} & \multicolumn{6}{|c|}{ Degree of Response } \\
\hline & & SA & $\mathrm{A}$ & $\mathrm{U}$ & $\mathrm{D}$ & SD & Total \\
\hline $\begin{array}{l}\text { Employees of commercial banking firms suffer } \\
\text { the consequences of stress affecting the }\end{array}$ & $\begin{array}{ll}\text { Top } & \text { level } \\
\text { Management } & \end{array}$ & 47 & 19 & 2 & 2 & 3 & 73 \\
\hline $\begin{array}{l}\text { performance output of employees in } \\
\text { commercial banking firms in Nigeria. (E.g. the }\end{array}$ & $\begin{array}{ll}\text { Middle level } \\
\text { Management }\end{array}$ & 75 & 44 & 2 & 3 & 2 & 126 \\
\hline $\begin{array}{l}\text { suffers from tension, heart attacks, increase } \\
\text { high blood pressure, anxiety, irritability, }\end{array}$ & $\begin{array}{ll}\text { Lower level } & \\
\text { Management } & \end{array}$ & 127 & 64 & 2 & 4 & 2 & 199 \\
\hline $\begin{array}{l}\text { absence from duty, job turnover, sleep } \\
\text { disorders, insomnia amongst others) }\end{array}$ & Total & 249 & 127 & 6 & 9 & 7 & 398 \\
\hline
\end{tabular}

Source: Field survey (2016). 
There has been overwhelming view among the respondents as indicated in table 3.0 above pertaining the consequences of stress as having a devastating effect on the performance output of employees in commercial banking firms in Nigeria. These consequence range from heartbeat, tension, anxiety, insomnia, employee turnover, absenteeism, sleep disorders, heart attacks, irritability, high blood pressure amongst others.

Thus, out of 398 respondents, 249 representing 63.31\% strongly agree on the subject matter that these stress symptoms and consequences have a devastating effect on the performance of employee. 127 subjects out of 398 representing 31. 90\% agree on the issue. 6 subjects out of 398 representing $1.50 \%$ were undecided on the issue. 9 out of 398 (or $2.26 \%$ ) disagree on the information. About 7 out of 398 (1.75\%) strongly disagree on the subject matter of consequence of stress as not affecting employees performance in the commercial banking firms in Nigeria.

\section{Hypothesis 2}

H02: The consequences of stress have no effect on the performance output of employees in commercial banking firms in Nigeria.

\begin{tabular}{|l|r|r|r|r|}
\hline Model & \multicolumn{1}{|c|}{ Model Summary } \\
\hline 1 & R Square & $\begin{array}{c}\text { Adjusted R } \\
\text { Square }\end{array}$ & $\begin{array}{c}\text { Std. Error of the } \\
\text { Estimate }\end{array}$ \\
\hline
\end{tabular}

The value of 0.834 indicates the consequences of stress have no effect on the performance output of employees in commercial banking firms in Nigeria. The R square is the coefficient of determination which is 0.696 with $69.6 \%$ proportion of variance in the dependent variable

ANOVAa

\begin{tabular}{|rl|r|r|r|r|r|}
\hline \multicolumn{1}{|c|}{ Model } & Sum of Squares & df & Mean Square & F & Sig. \\
\hline \multirow{2}{*}{1} & Regression & 8.632 & 6 & 1.439 & 12.600 & $.000^{\mathrm{b}}$ \\
& Residual & 3.768 & 33 & .114 & & \\
& Total & 12.400 & 39 & & & \\
\hline
\end{tabular}

The table shows that the independent variables are statistically significantly, $F(6,33)=$ $12.600, \mathrm{P}<0.05$. We reject the hypothesis which states that the consequences of stress have no significant effect on the performance output of employees in commercial banking firms in Nigeria. 


\section{Coefficients ${ }^{\mathrm{a}}$}

\begin{tabular}{|c|c|c|c|c|c|c|}
\hline \multirow{2}{*}{\multicolumn{2}{|c|}{ Model }} & \multicolumn{2}{|c|}{$\begin{array}{c}\text { Unstandardized } \\
\text { Coefficients }\end{array}$} & \multirow{2}{*}{$\begin{array}{c}\text { Standardized } \\
\text { Coefficients } \\
\text { Beta }\end{array}$} & \multirow[t]{2}{*}{$\mathrm{t}$} & \multirow[t]{2}{*}{ Sig. } \\
\hline & & $\mathrm{B}$ & Std. Error & & & \\
\hline \multirow{7}{*}{1} & (Constant) & 1.800 & .452 & & 3.979 & .000 \\
\hline & Suffer from tension & .271 & .064 & .474 & 4.220 & .000 \\
\hline & Heart attack & .137 & .046 & .298 & 2.999 & .005 \\
\hline & High blood pressure & .300 & .076 & .447 & 3.954 & .000 \\
\hline & Anxiety & .075 & .056 & .132 & 1.336 & .019 \\
\hline & Irritability & .007 & .045 & .015 & .150 & .028 \\
\hline & Sleep disorder & .031 & .049 & .072 & .640 & .027 \\
\hline
\end{tabular}

a. Dependent Variable: Performance of Commercial Bank

Interpretation.

$\mathrm{y}=\mathrm{X} 1+\mathrm{X} 2+\mathrm{X} 3+\mathrm{X} 4+\mathrm{X} 5+\mathrm{X} 6$ where $\mathrm{C}$ is the constant.

Predicted $\mathrm{y}=0.271 \mathrm{X} 1+0.137 \mathrm{X} 2+0.300 \mathrm{X} 3+0.075 \mathrm{X} 4+0.007 \mathrm{X} 5+0.031 \mathrm{X} 6+1.800$

The consequences of stress have a positive relationship on the performance of the commercial banking firms in Nigeria.

\section{DISCUSSION OF FINDINGS}

The findings from the test of formulated hypotheses revealed interesting results as follows;

For Hypotheses one (1), it was found that strategies for the management of stress adopted by commercial banking firms in Nigeria have impacted positive on the performance of the banks. These strategies include time management, relaxation strategies, placement of employee in appropriate jobs, realistic goal settings, designing jobs with employee needs and skills in mind, improvement in organizational communication, establishment of corporate wellness programs, delegation of authority, seeking for counseling and guidance, being happy and humorous, employment of workers that are suitable for the job.

This is also manifest in the value of 0.839 obtained in the regression analysis which indicates that strategies for management of stress here significantly impacted on the performance of the commercial banking organizations in Nigeria. The R square is the coefficient of determination which is 0.704 with $70.4 \%$ proportion of variance in the dependent variable.

Previous empirical researches from $[4,16,6,23]$ confirms that the key factors which represents potential sources of stress include external environment (i.e economic situation, technological development), organizational structure and culture (i.e nature of Job structure, management style etc), work relationships (i.e quality of relationship with colleagues, boss, own staff etc), Job characteristics (i.e challenge, power etc), personal factors (i.e personality, motivation, intellect, skills etc), domestic/social situations (i.e illness, bereavement, debt). All these factors can cause individual stress in organization. Steps that management can take to reduce the experience of stress among their work force can be considered as stress avoidance measures and stress reduction measures. 
Enumerated stress avoidance countermeasures as follows;

a) Design jobs to permit maximum use of skills and discretion by job-holders and incorporate sufficient task variety and challenge to maintain employee interest.

b) Design work so as to permit exercise of responsibility by job holders, giving sufficient authority, and allowing job-holders to share in decision making process that affect his or her work and ensuring work goals that do not conflict with those of others.

c) Encourage superiors to develop participative management style, paying attention to individual needs as well as those of the task and the group.

d) Encourage team-spirit; where team-members support each other and individuals are valued for their role.

e) Encourage communication between departments/sections as well as vertically through the management chain and provide constructive feedback to individuals (by job results, staff appraisal, etc).

f) Ensure that decision-making is delegated so that people at every level are able to share in decision affecting their work and future prospects.

g) Develop an organization culture in which attitudes towards employees are positive and where attention to product/service quality is reflected in respect for employee's knowledge, skills and contribution, and where mistakes are seen as learning opportunities rather than grounds for criticism.

The stress reduction measure advanced by him includes;

a) Reduce the number of changes expected of any one individual or team.

b) Limit the procedural and other complexities associated with the execution of tasks.

c) Permit individuals to express their feelings and anxieties to someone else-boss, colleagues and trained counselors.

d) Provide sports and social facilities.

e) Provide adequate canteen and rest-room facilities.

The implication of the above scenario is that executive management of the commercial banks in Nigeria should endeavor to provide adequate training awareness and sensitization campaigns and workshop forums to properly educated employees of the enormous associated benefits that accompany stress management. Professional counseling in the workplace using techniques that can help individual employees take responsibility for and to manage their own decision making whether work related or personal is necessary. [9] maintains that skilled helpers through interactions are in a better position to manage problems situations that confronts employees and keep them develop mindset and opportunities of their lives more meaningfully that will make them to be productively oriented.

For Hypotheses two (2), it was revealed that the consequences of stress have a significant effect on the performance output of employees in commercial banking firms in Nigeria. Stress can cause high blood pressure, ulcer, irritability, difficulties in taking simple decision relate to work, loss of one's appetite, easy susceptibility to mistakes and accidents, anger and aggressiveness, headache, vomiting symptoms.

Maintains that, these symptoms have physiological effect, psychological effect and behavior effect. The physiological effect, includes increase heartbeat, obsession, constant headache and migraine, heart disease/cardiac arrest, changes in one metabolism etc. The psychological effect includes job dissatisfaction, tension, anxiety, boredom, procrastination, laziness, anger, emotional instability and lack of contraction etc. The behavior effect includes low productivity and profitability, absenteeism, low turnover rate, change in eating habit, stammering, disorder in one's sleep, aggression, hot tempered, quarreling etc. 
The policy implication in this regard demands that the executive management should engage medical personnel/Doctors to give constant medical check-ups to employees to ensure that they are all right as they perform their task on the day to day basis to guarantee goal attainment of profit, growth, productivity, survival, continuity amongst others.

\section{CONCLUSION AND RECOMMENDATIONS}

It is important for organizations employees to know the potential sources of stress, their accompanying symptoms and consequences. This will facilitate its proper management in the organization either through stress-avoidance counter measures and stress-reduction measures. Proper understanding and identification of the individual stressors, group stressors causing stress and the personality traits possessed by employees either type A personality traits or type B personality traits will help executive management of commercial banking firms in Nigeria to deal with this ugly phenomenon in a better manner to yield productivity. This is pertinent because, type A personality employees experienced considerable stress than type B personality employees. Applying the right management strategies by organizations management with the understanding of the stress symptoms and consequences will help in addressing this ugly devastating occurrence.

Based on the above, the paper recommendations are as follows;

1. Assigning of responsibilities and tasks to employees for performance that are inexperienced and unskillful and those who will not live up to expectations of the job assignment leading to role conflict should be checkmated and avoided by organization management. Human resource department should endeavor to employ and assigned task to competent employees with requisite skills for a viable results.

2. Role ambiguity and lack of clarity to assigned tasks and responsibilities by the human resources departments of banking organization be avoided and discouraged to ensure organizational effectiveness.

3. Proper delegation of authority for specific tasks and responsibilities to employees of banking firms is important. This will enable them know their boundary of effective operation leading to avoidance of stress in organizations.

4. Proper job descriptions to employees is pertinent hence this will ensure effective commitment, loyalty, dedication to quality service delivery thus eliminating alienating stressful aspects of the job.

5. Strategies for effective management of stress such as proper time management, improvement of organizational communications, exercise and fitness programme, staff counseling, job design and enrichment strategies, improved selection and training mechanism, development of team working systems, relaxation technique, prioritizing activities by importance and urgency, expanding your social support network to reduce tension amongst others be adopted by employees of banking firms and awareness and sensitization campaigns by executive management of banks to guarantee direction on how best to manage stress in workshop forums will curb the menace of stress and facilitates attainment of organizational goals .

6. Determination of job objectives is a viable strategy for stress management and assignment of responsibility. Through this what is required to be achieved is established to be followed and pursued, making life easy for employees by avoiding and eliminating the stressful element that would have associated with the job.

7. Qualified medical personnel be employed by the commercial banking firms specifically to manage and treat stress related symptoms of the headache, increase blood pressure, increase breathing rates, induced heart attacks, tensions, anxiety, sleep disorders, 
insomnia amongst others. Proper treatment will help reposition performance status of the organization.

8. Organization management should endeavor to determine the personality traits possessed by employees and ensure that they are appropriately advised, counseled to adopt the right posture to life as they go about on their work assignment and responsibilities. They have to realize that been patient and planning their responsibilities on daily basis will help reduce stress element associated with jobs.

\section{References}

1. Baridam, D. Research Methods in Administrative Science. Choba-Port-Harcourt, University of Port Hracourt Publishing House, 2001.

2. Buchanan, D. and Huczynski, A. Organizational Behaviour: An Introductory text. 5th Edition; Harlow: FT Prentice Hall Financial Times, 2004.

3. Carminess, EG and Zeller. Reliability and Validity Assessed, Sage: Beverly Hills, 1979.

4. Chinonye, LE. Entrepreneurship: A Conceptual Approach: Lagos: concept publication Ltd, 2002.

5. Clark, D. Stress Management; Cambridge: National Extension College publishing, 1989.

6. Cole, GA. Personnel and Human Resources Management. 5th edition; London: Continnium Ltd, 2002.

7. Daft, RL. New Era of Management. 2nd Edition. Austraila: Thomson- South-Western publishers, 2008.

8. De Vellis, RF. “Scale development”, Newbury Park: Sage publication, 1991.

9. Egan, G. The skilled Helper. 4th edition; Brooks: Cole publishing, 1990.

10. Friedman, M and Rosenman, RE. Type A Behaviour and your Heart. New York: Knopf, 1974.

11. Gay, LR. Educational Research: Competencies for Analysis and Application, 5th Edition; Columbus Ohio: Merrill Publishing Company, 1996.

12. Griffins, RW. Management. 5th Edition; New Delhi: A.I.T.B.S. publishers and distributors (Regd), 1997.

13. Handy, CB. Understanding Organizations. 4th Edition, New York: Penguin Publisher, 1993.

14. Ivancevich, JM, and Matteson, MT. Stress and Work (Glenview; 11: Scott, Foresman, 1981); and R.D. Allen, M.A. Hitt, and C.R. Greer, "Occupational stress and perceived Organizational Effectiveness in Formal Groups: An Examination of stress level and stress type, "personnel psychology"; summer 1982, pp359-70, 1981.

15. Langton, N; Robbins, SP, and Judge, TA. Organizational Behaviour: Concepts, Controversies, Applications. 5th Canadian Edition, Toronto: Pearson Canada, 2010.

16. Luthans, F. Organizational Behaviour. 9th edition; Boston: McGraw-Hill Higher Education publishers, 2007.

17. Malhotra, W. Marketing Research: An Implied Orientation, New York: Prentice. Hall publishers, 1999.

18. Managers under stress: A survey of Management Morale in the 90s. The Institute of Management, December, 1993.

19. Mikenna, E. Business Psychology and Organizational Behaviour. Lawrence Eribaun, 1994.

20. Mcshane, SL and Von Glinow, MA. Organizational Behaviour, Boston: McGraw-Hill Publishers, 2000.

21. Mullins, LJ. Management and Organizational Behavior. 4th edition; London: Pitman Publishing, 1996.

22. Nunnally, JC. “Psychometric Theory”, 2nd Edition; New York: McGraw-Hill publishing, 1999.

23. Robbins, SP. Organizational Behaviour: Concepts, Controversies and Applications; International Edition; New Jersey: Prentice Hall, 1989. 
24. Schermerhorn, JR; Hunt, JG and Osborn, RN. Organizational Behaviour. 9th Edition; Ohio: John Wiley and Sons Inc, 2005.

25. Sev, JT. Organizational Behaviour: Concepts and Applications, Revised Edition; Makurdi. Traces printing and Publishing company, 2006.

26. Yamane, T. Statistics: An Introductory Analysis, New York: Harper and Row Publishing House, 1964.

\section{APPENDIX I}

Department of Business Management

Faculty of Management Sciences

Benue State University,

Makurdi, Nigeria.

1st December, 2016.

\section{Dear Sir/Madam,}

You have been chosen as one of the respondent in this study. You are therefore humbly requested to supply honesty and sincere answers/responses to the questions by ticks $(\sqrt{ })$ there is no right or wrong answers.

\section{Questionnaire}

Strategies adopted for managing stress by banking organization in Nigeria include individual approaches (i.e time management, relaxation techniques, building social support and organizational approaches (e.g placement of staff on appropriate jobs, realistic goal settings, designing jobs with employee needs and skills) amongst others.
a) Strongly Agree (SA)
b) Agree (A)
c) Undecided (U)
d) Disagree (D)
e) Strongly Disagree (SD)

These strategies for managing stress have enhanced performance goals attainment in banking firm in Nigeria.
a) Strongly Agree (SA)
b) Agree (A)
c) Undecided (U)
d) Disagree (D)
e) Strongly Disagree (SD)

The consequences of stress have negative effect on the performance output of employees in commercial banking firms in Nigeria. (E.g. Heart attacks increase blood pressure, tension, anxiety, irritability amongst others).
a) Strongly Agree (SA)
b) Agree (A)
c) Undecided (U)
d) Disagree (D)
e) Strongly Disagree (SD) 